\title{
PENJADWALAN MUBALIGH ONLINE PADA PERSATUAN MUBALIGH DUMAI (PMD) KOTA DUMAI
}

\author{
Pulla Pandika Widodo ${ }^{1}$, Elisawati ${ }^{2}$ \\ ${ }^{1,2}$ Sekolah Tinggi Managemen Informatika dan Komputer (STMIK) Dumai \\ Jl.Utama Karya Bukit Batrem II Dumai-Riau kode pos 28811 \\ E-mail : pullapandika@gmail.com
}

\begin{abstract}
ABSTRAK
Persatuan Mubaligh Dumai atau yang disingkatkan dengan nama PMD Kota Dumai merupakan wadah seluruh kegiatan Mubaligh yang ada dikota Dumai yang sudah diatur dan dijadwal. Dalam menjadwal Mubalig ini masih sering salah memberikan jadwal kepada mubalig hal ini disebabkan masih menggunakan penulisan pada kertas untuk menyusun jadwal, perlu adanya sistem penjadwalan mubaligh berbasis website dengn menggunakan pemrogmran php yang datanya tersimpan di dalam database dan penyajian informasi dapat langsung dilihat pada website yang tersedia. Sehingga hal ini dapat mempermudah mubalig dalam melihat jadwal ceramah tidak perlu lagi datang kekantor.
\end{abstract}

Kata kunci : Mubaligh, Penjadwalan, Dumai

\section{PENDAHULUAN}

Persatuan Mubaligh Dumai atau yang disingkatkan dengan nama PMD Kota Dumai berlokasi dijalan H.R.Soebrantas Dumai Mesjid Habiburrahman Telp.0765-38086. Sejak berdirinya Persatuan Mubaligh Dumai (PMD) Kota Dumai seluruh kegiatan Mubaligh yang ada dikota Dumai diatur dan dijadwal sehingga disetiap kegiatan acara hari besar seperti, Khutbah Juma'at, Siraman Rohani Ramadhan, Idul Fitri, Idul Adha, Isra Mijraj Nabi Muhammad Saw, Tahun Baru Islam, Maulid Nabi Muhammad Saw dan lain-lain seluruhnya sama baik tema maupun judul. Hal ini tentu saja memberikan efek positif bagi masyarakat Kota Dumai karena kesamaan materi yang didapat.

Pengurus Persatuan Mubaligh Dumai (PMD) Kota Dumai dalam menjalankan tugasnya selalu dibantu oleh anggota untuk menyusun jadwal khutbah/ceramah namun demikian tetap saja terdapat kesalahan dalam memberikan jadwal kepada mubalig, hal ini dikarenakan penyusunan masih menggunakan penulisan pada kertas untuk menyusun jadwal.

Hal ini disebabkan karena sistem komputerisasi dalam Kantor PMD ini belum berjalan. Pengembangan sistem penjadwalan Mubaligh bertujuan untuk menciptakan kinerja yang efektif dan efesien, karena lebih mudah mendapatkan informasi dan tidak perlu membuang banyak tenaga, waktu dan biaya yang harus dikeluarkan mubaligh untuk melihat jadwalnya masing - masing kekantor PMD Kota Dumai. Melalui pengembangan sistem penjadwalan Mubaligh dengan layanan online ini diharapkan dapat mempermudah Mubaligh untuk mendapatkan informasi secara lengkap.

\section{a. Pengembangan Sistem}

Pengembangan sistem (systems development) dapat berarti menyusun suatu sistem yang baru untuk menggantikan sistem yang lama secara keseluruhan atau memperbaiki sistem yang telah ada.

Proses tradisional untuk melakukan pengembangan sistem informasi dinamakan siklus hidup pengembangan sistem (Systems Development Life Cycle/SDLC) yang memuat langkah-langkah yang semestinya diikuti oleh profesional di bidang sistem informasi, seperti perancangan basis data dan pemrogram, untuk menspesifikasikan, mengembangkan, serta memelihara sistem informasi (Nugroho, 2011).

Pengembangan sistem merupakan tanggung jawab semua yang terlibat, tidak hanya sematamata bagian ICT. tampa input yang lengkap dan benar dari users sudah tentu ICT tidak dapat membangun sistem. pengetahuan operasional yang dimiliki oleh pemakai, tidak dapat dimiliki ICT. Pengetahuan ICT hanya sebatas pengaplikasian informasi yang diberikan dengan menggunakan teknologi dan mencari solusi untuk menunjangnya (Nugroho, 2011). 


\section{INFORM T I K}

Jurnal Informatika, Manajemen dan Komputer, Vol. 9 No. 2, Desember 2017

eISSN : 2580-3042

pISSN : 1979-0694

\section{b. Pengertian Sistem}

Pengertian sistem terbagi beberapa bagian yaitu, dilihat dari pendekatan yang melakukan pada prosedurnya dan pendekatan yang menekankan pada elemennya atau komponennya adapun beberapa defenisi sistem antara lain :

Menurut Hanif Al Fatta (Hanif Al Fatta, 2007) Sistem adalah suatu kumpulan atau himpunan dari unsur atau variabel-variabel yang saling terorganisasi, saling berinteraksi, dan saling bergantung sama lain.

Menurut Jogiyanto (Jogiyanto HM, 2009b) Sistem dapat didefinisikan dengan pendekatan prosedur dan dengan pendekatan komponen. Dengan pendekatan prosedur, sistem dapat didefinisikan sebagai kumpulan dari prosedurprosedur yang mempunyai tujuan. Sedangkan pendekatan komponen, sistem dapat didefinisikan kumpulan dari komponen yang saling berhubungan satu dengan yang lainnya membentuk satu kesatuan untuk mencapai tujuan tertentu.

\section{c. Sistem Informasi}

Menurut Hanif Al Fatta (Hanif Al Fatta, 2007), Sistem informasi adalah data yang telah diolah menjadi sebuah bentuk yang berarti bagi penerimanya dan bermanfaat dalam pengambilan keputusan saat ini atau mendatang.

Sistem informasi adalah suatu sistem didalam suatu organisasi yang mempertemukan kebutuhan pengelolahan transaksi harian, mendukung operasi, bersifat manajerial dan kegiatan strategi dari suatu organisasi dan menyediakan pihak luar tertentu dengan laporanlaporan yang diperlukan (Jogiyanto HM, 2009).

\section{d. Penjadwalan}

Penjadwalan adalah suatu proses pengalokasian sumber daya dan mesin yang tersedia untuk menyelesaikan suatu pekerjaan dengan mempertimbangkan batasan-batasan yang ada (Mangngenre et al., n.d.).

\section{e. Mubaligh}

Menurut (Kurnia, 2014) mubalig yaitu sebagai pendidik, penyedia layanan, administrator/manajer, murid, dan yang terakhir adalah peneliti. Peran mubalig sebagai seorang pendidik disepakati sebagai peran yang paling utama. Hal tersebut sejalan dengan yang diungkapkan oleh Ahmad Dahlan (dalam Sairin, 2008) yang juga menuturkan bahwa mubalig/mubalighah merupakan pakar pendidik ilmu agama.

\section{f. $\quad$ Notepad ++}

Notepad ++ adalah sebuah penyunting teks dan penyunting kode sumber yang berjalan di sistem operasi Windows. Notepad ++ menggunakan komponen scintilla untuk menampilkan dan mengedit teks maupun berkas kode sumber beragam bahasa pemograman (Ignas, 2014)

Berikut adalah fungsi notepad ++ :

a. Notepad sebagai digital library : kita dapat menggunakan notepad digital library dan secara otomatis untuk memasukkan tanggal dan informasi waktu.

b. Notepad sebagi HTML stripper. Kita dapat mengedit komponen teks saja. Dengan menyalin dari kode HTML yang ada di halaman web dan paste ke notepad yang kemudian Dapat disimpan untuk digunakan lagi lain waktu.

c. Notepad sebagai pembuat script. Kita dapat membuat script yang kompleks.

d. Notepad sebagai jalan pintas windows explorer. Ada file yang tidak bisa dihapus denga notepad kita bisa memcoba menghapus file tersebut dengan cara file > open > pada type file pilih all.

e. Untuk mengedit file berektensi.

Membuat / mengedit file berektensi reg.

Reg adalah file yang digunakan untuk memasukkan pengaturan windows melalui registry windows (Ignas, 2014).

\section{METODOLOGI PENELITIAN}

Metodologi penelitian berisi bagan kerangka penelitian serta penjelasan dari bagan kerangka penelitian tersebut.

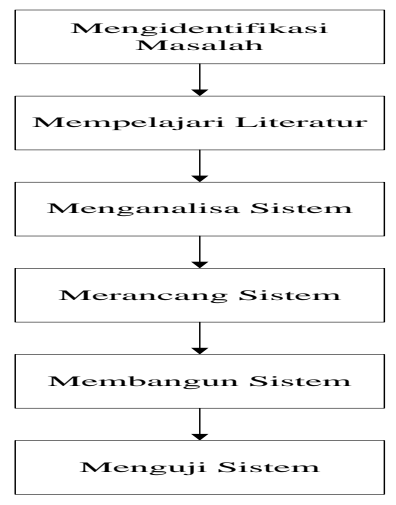

Gambar 1. Kerangka Penelitian

Berdasarkan gambar 1 dapat dijelaskan bahwa:

1. Mengidentifikasi Masalah

Pada tahap ini dilakukan peninjauan terhadap masalah yang akan di teliti untuk 
I N F O R M A T I K A

Jurnal Informatika, Manajemen dan Komputer, Vol. 9 No. 2, Desember 2017

eISSN : 2580-3042

pISSN : 1979-0694

memahami bentuk perekapan data dan penyajian informasi.

2. Studi Literatur

Studi literature dilakukan di pustaka untuk mengumpulkan keterangan berdasarkan referensi, buku-buku, jurnal, dan yang berkaitan dengan analisa perancangan system informasi, agar data yang di dapatkan bisa dijadikan acuan untuk menyelesaikan permasalahan dalam studi kasus ini.

3. Menganalisis Masalah

Mengamati dan menguraikan data-data yang telah dikumpulkan untuk diteliti lebih lanjut baik dari wawancara maupun dari observasi tentang permasalahan Penjadwalan Mubaligh.

4. Perancangan Aplikasi

Perancangan sistem pada tahap ini dilakukan proses desain sistem di mulai dengan penyajian basis data, perancangan aliran sistem informasi, DFD, context diagram, ERD, desain input, desain output dan hasil analisis data-data tersebut digunakan untuk membentuk suatu aplikasi baru yang telah dirancang.

5. Pembuatan Aplikasi

Setelah tahapan perancangan aplikasi dilakukan maka langkah selanjutnya adalah pembuatan aplikasi untuk menjalankan operasi komputer dengan menggunakan bahasa pemograman php berbasis web.

6. Pengujian Aplikasi

Setelah aplikasi yang dirancang telah selesai dibuat maka perlu dilakukan pengujian apakah aplikasi ini bisa berjalan sesuai dengan yang telah direncanakan dan sesuai dengan tujuan penelitian.

\section{HASIL DAN PEMBAHASAN}

Hasil dan pembahasan berisi tentang pembahasan serta hasil akhir atau output program atau analisa metode dari penelitian tersebut.

\section{a. Context Diagram}

Context Diagram merupakan gambaran umum dari sistem yang diarancang, untuk lebih jelas dapat dilihat seperti dibawah ini :

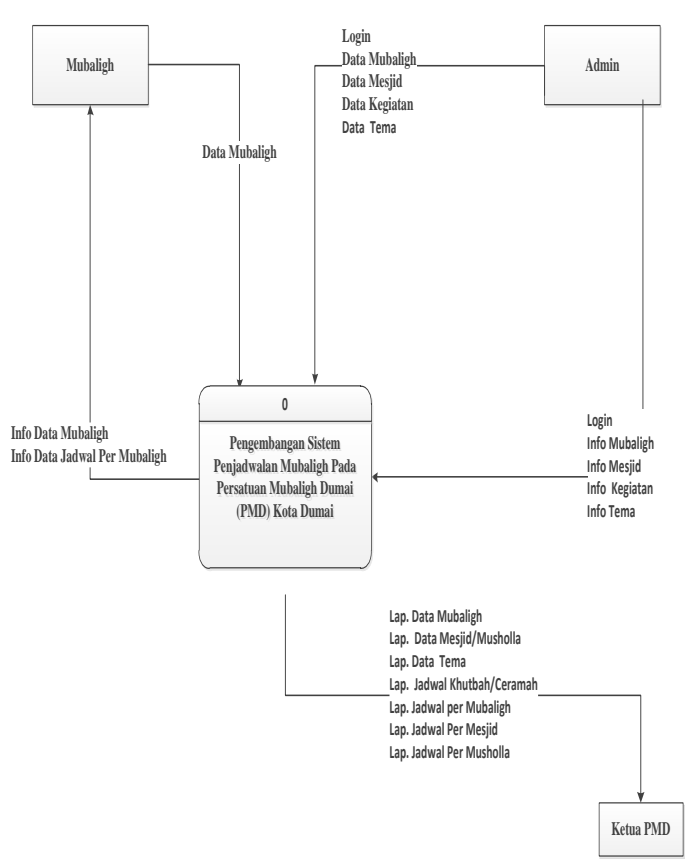

Gambar 2. Context Diagram

b. Data Flow Diagram (DFD)

Data Flow Diagram memperlihatkan aliran data masuk dan keluar melalui database.

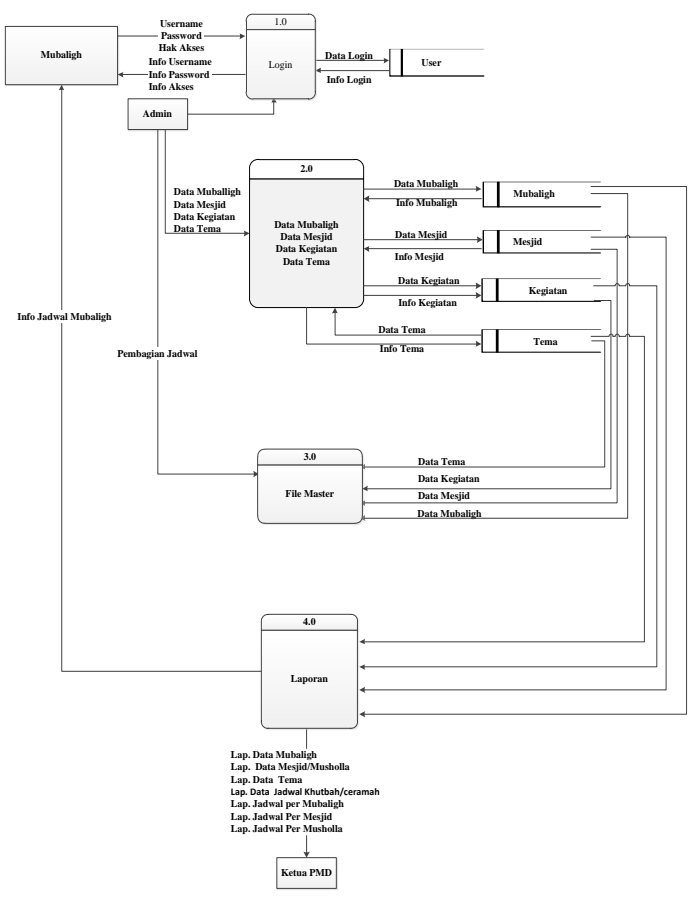

Gambar 3. Data Flow Diagram 
I N F ORM A T I R

Jurnal Informatika, Manajemen dan Komputer, Vol. 9 No. 2, Desember 2017

eISSN : 2580-3042

pISSN : 1979-0694

\section{c. Entity Relation Diagram (ERD)}

Entity Relation Diagram (ERD) merupakan relasi antar tabel di dalam database yang terjadi untuk memenuhi kebutuhan.

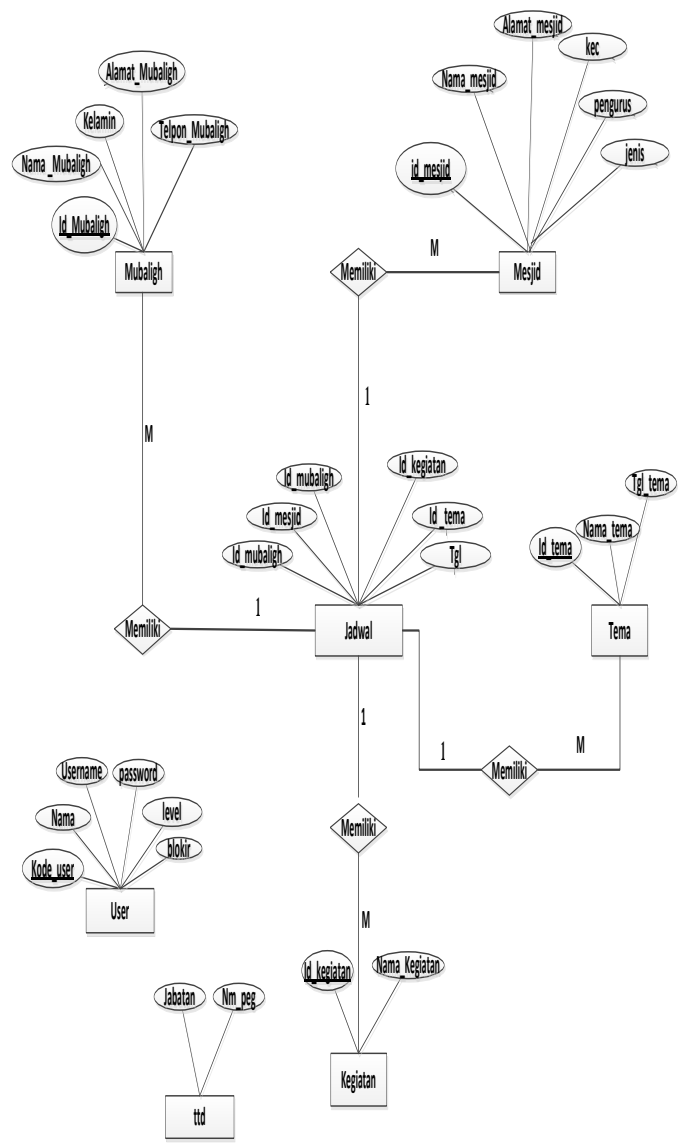

Gambar 4. Entity Relationship Diagram

\section{d. Form Login Admin}

Jalankan program aplikasi dengan cara mengklik icon program aplikasi. Setelah itu maka akan muncul form Login. masukkan Hak Akses dan Password. Jika setelah diisi dengan benar,klik Login maka menu utama aplikasi akan tampil.

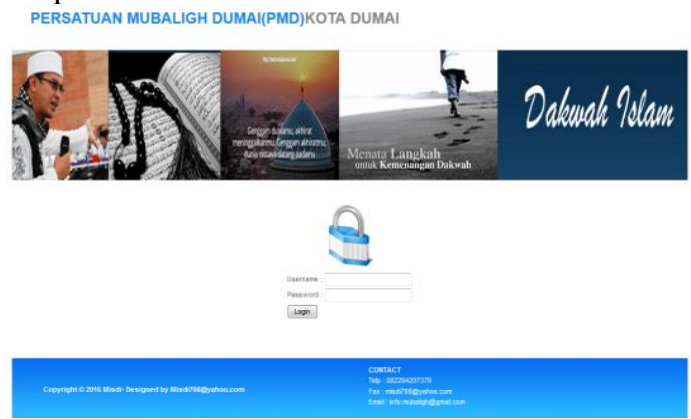

Gambar 5. Halaman Login Admin

\section{e. Menu Utama (HOME)}

Setelah mengisi form login dengan benar, maka pengguna langsung bisa melihat Menu Utama.

$$
\text { Welcome }
$$

PERSATUAN MUBALIGH DUMAI(PMD)KOTA DUMAI

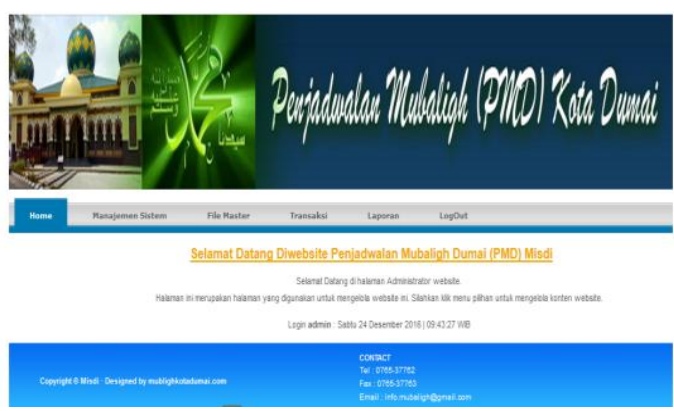

Gambar 6. Menu Utama (Home)

Pada Menu Utama, terdapat beberapa submenu yang memiliki fungsi dan kegunaanya masing-masing, yaitu:

1. Klik submenu Manajemen sistem untuk menginputkan Manajemen User dan Manajemen Ttd

2. Klik submenu File Master untuk menginputkan atau menampilkan Data Mubaligh, Data Musholla, Data Kegiatan dan Data Tema.

3. Klik submenu Transaksi untuk menginputkan atau menampilkan Jadwal Khutbah / Ceramah

4. Klik submenu Laporan untuk menampilkan form cetak laporan.

5. Klik submenu LogOut jika ingin keluar dari aplikasi.

\section{f. Form Input Data User}

Pada Menu Utama, klik Pada Manajemen sistem kemudian pilih Manajemen user untuk menambah atau menghapus user.

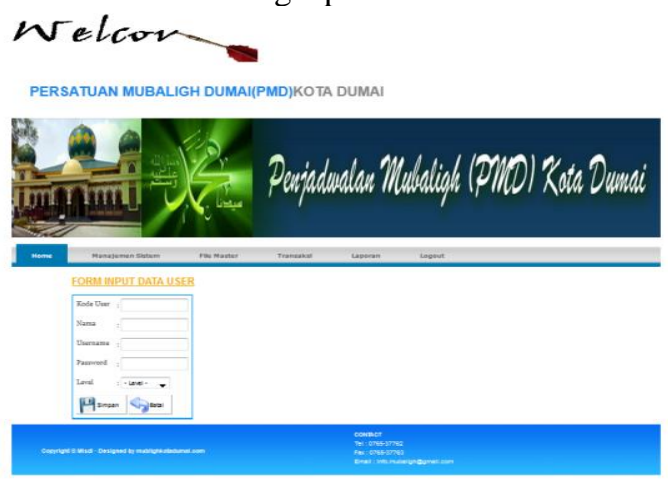

Gambar 7. Form Input Data User 
IN F O R M A T I A

Jurnal Informatika, Manajemen dan Komputer, Vol. 9 No. 2, Desember 2017

eISSN : 2580-3042

pISSN : 1979-0694

- Isi kode User, Nama, Username dan Password berserta pilih level (dipilih admin atau Pengurus), setelah semua terinput pilih tombol "simpan atau Batal" untuk menyimpan atau membatalkan data.

- Jika ingin mengubah data yang telah disimpan, pilih pada opsi "gambar pensil" untuk memanggil data akun anda, lalu ubah data sesuai yang diinginkan setelah itu klik "Update atau Batal”.

- Jika ingin menghapus data yang telah disimpan pilih pada opsi "gambar x" untuk memanggil data akun anda, lalu klik.

- "Batal" untuk menclearkan data yang dinput.

\section{g. Form Input Ubah TTD}

Pada Menu Utama, klik pada

manajemen sistem kemudian pilih Manajemen TTD untuk mengubah Ttd, maka akan tampil form seperti gambar 36 dibawah ini :

$$
\text { Welcome }
$$

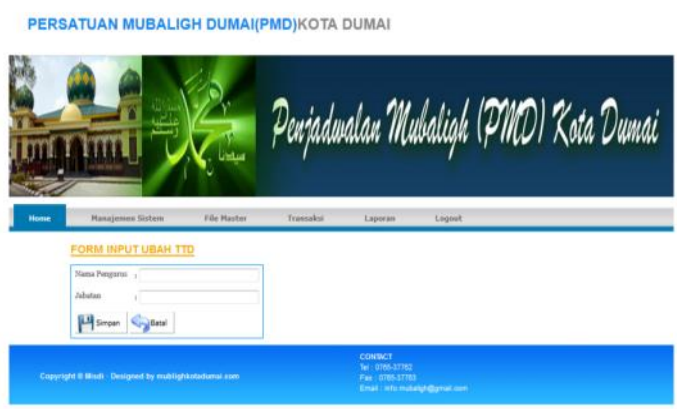

Gambar 8. Form Input Ubah TTD

\section{h. Form Input Data Mubaligh}

Pada Menu Utama, klik pada File Master kemudian pilih Data Mubaligh berisi informasi data-data yang berkaitan dengan data Mubaligh.

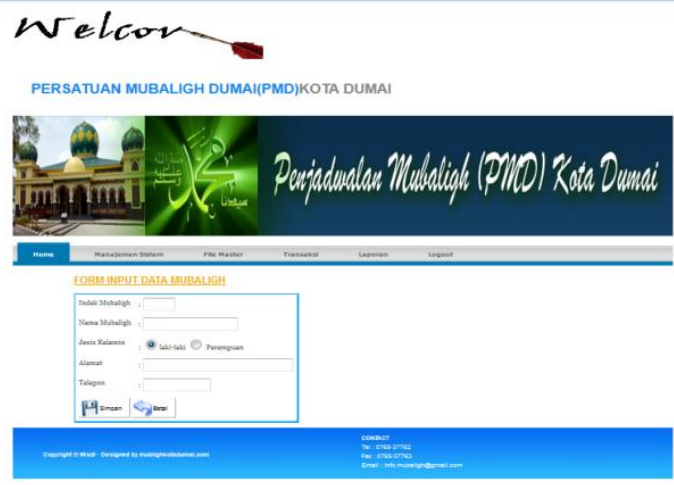

Gambar 9. Form Input Data Mubaligh 
I N F ORM A T I R

Jurnal Informatika, Manajemen dan Komputer, Vol. 9 No. 2, Desember 2017

eISSN : 2580-3042

pISSN : 1979-0694

\section{j. $\quad$ Form Input Data Kegiatan}

Pada Menu Utama, klik pada file master kemudian pilih Data Kegiatan berisi informasi data-data yang berkaitan dengan data kegiatan.

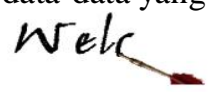

PERSATUAN MUBALIGH DUMAI(PMD)KOTA DUMAI

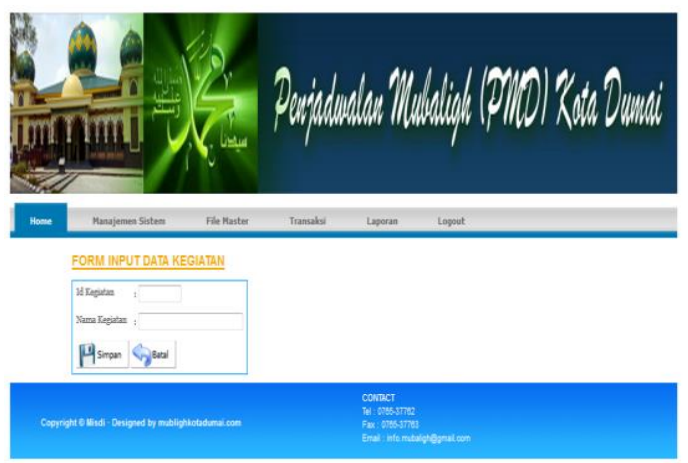

Gambar 11. Form Input Data Kegiatan

- Isi Id Kegiatan dan Nama Kegiatan setelah semua terinput pilih tombol "simpan atau Batal" untuk menyimpan atau membatalkan data.

- Jika ingin mengubah data yang telah disimpan, pilih pada opsi "gambar pensil" untuk memanggil data akun anda, lalu ubah data sesuai yang diinginkan setelah itu klik "Update atau Batal".

- Jika ingin menghapus data yang telah disimpan pilih opsi "gambar x" untuk memanggil data akun anda, lalu klik.

- "Batal" untuk menclearkan data yang dinput.

\section{k. Form Input Data Tema}

Pada Menu Utama, klik pada File Master kemudian pilih Data Tema berisi informasi datadata yang berkaitan dengan data tema.
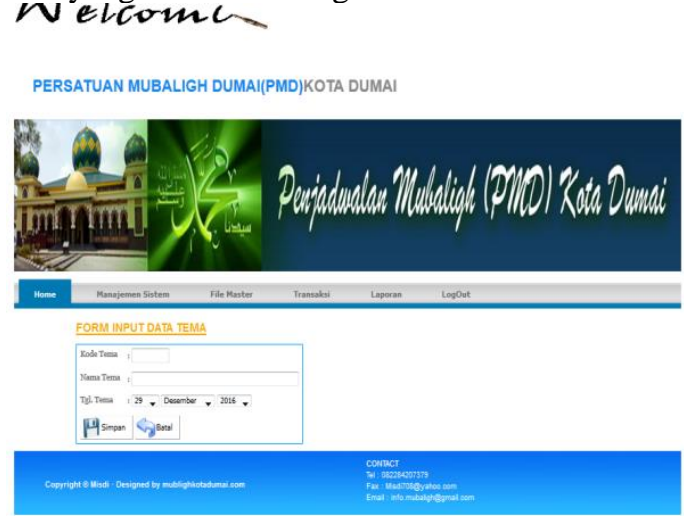

Gambar 12. Form Input Data Tema

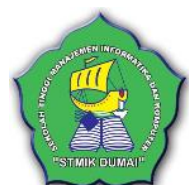

- Isi Kode Tema, Nama Tema dan Tanggal Tema setelah semua terinput pilih tombol "simpan atau Batal" untuk menyimpan atau membatalkan data.

- Jika ingin mengubah data yang telah disimpan, pilih pada opsi "gambar pensil" untuk memanggil data akun anda, lalu ubah data sesuai yang diinginkan setelah itu klik "Update atau Batal".

- Jika ingin menghapus data yang telah disimpan pilih opsi "gambar x" untuk memanggil data akun anda, lalu klik.

- "Batal" untuk menclearkan data yang dinput.

\section{Form Input Data Jadwal}

Pada Menu Utama, klik Pada Transaksi kemudian pilih Jadwal berisi informasi data-data yang berkaitan dengan data master.
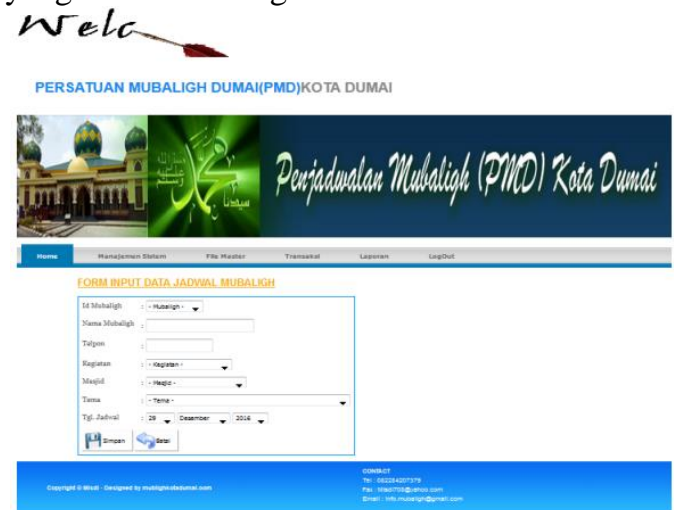

Gambar 13. Form Input Data Jadwal

\section{m. Laporan Data Mubaligh}

Pada Menu Utama, pilih Laporan Data Mubaligh maka akan tampil form Data Mubaligh seluruhnya seperti gambar 14 dibawah ini :

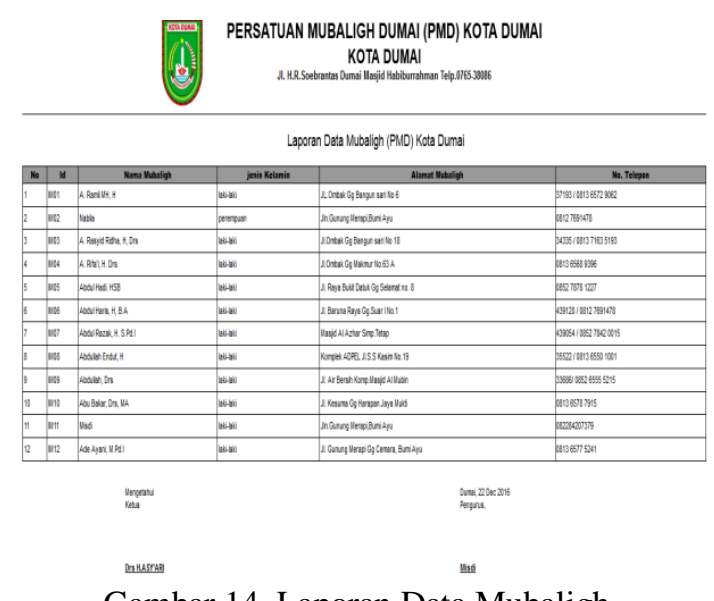

Gambar 14. Laporan Data Mubaligh 
I N F ORM A T I R

Jurnal Informatika, Manajemen dan Komputer, Vol. 9 No. 2, Desember 2017

eISSN : 2580-3042

pISSN : 1979-0694

n. Laporan Data Mesjid/Musholla

Pada Menu Utama, pilih Laporan Data

Mesjid/Mushola maka akan tampil form Data Mesjid/Musholla seluruhnya seperti gambar 15 dibawah ini :
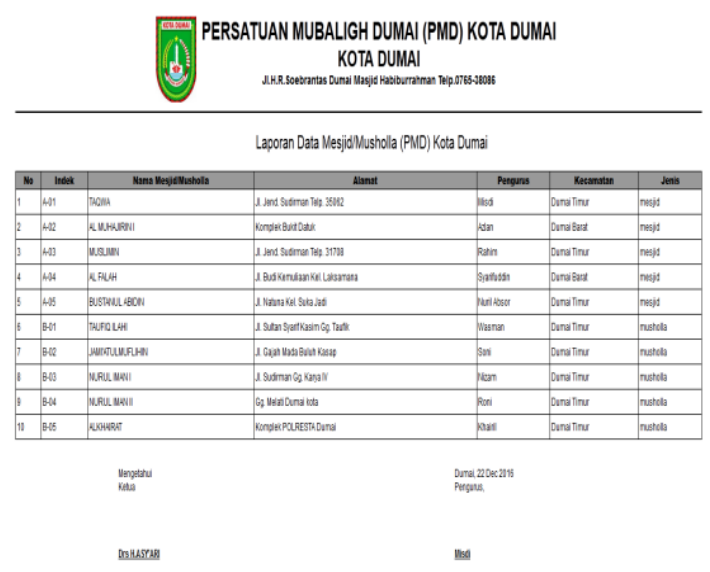

Gambar 15. Laporan Data Mesjid/Musholla

\section{o. Laporan Data Tema}

Pada Menu Utama, pilih Laporan Data Mubaligh maka akan tampil form Data Mubaligh seluruhnya seperti gambar 16 dibawah ini :

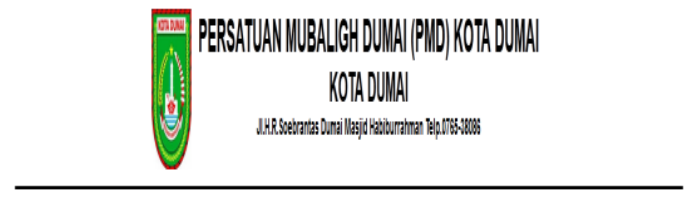

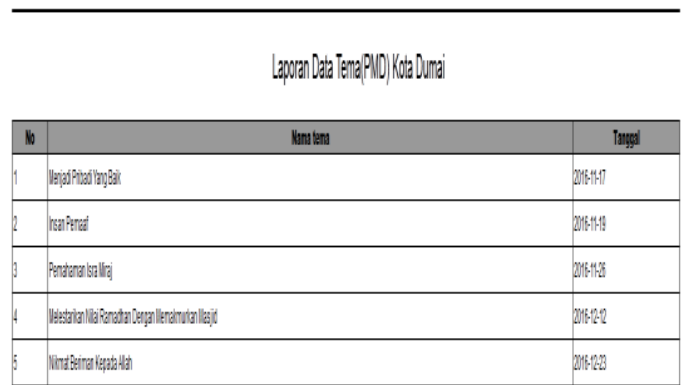

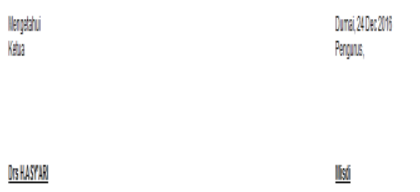

Gambar 16. Laporan Data Tema

p. Laporan Data Jadwal Khutbah/Ceramah

Pada Menu Utama, pilih Laporan Data Jadwal khutbah/ceramah maka akan tampil form Data Jadwal khutbah/ceramah seluruhnya seperti gambar 17 dibawah ini :

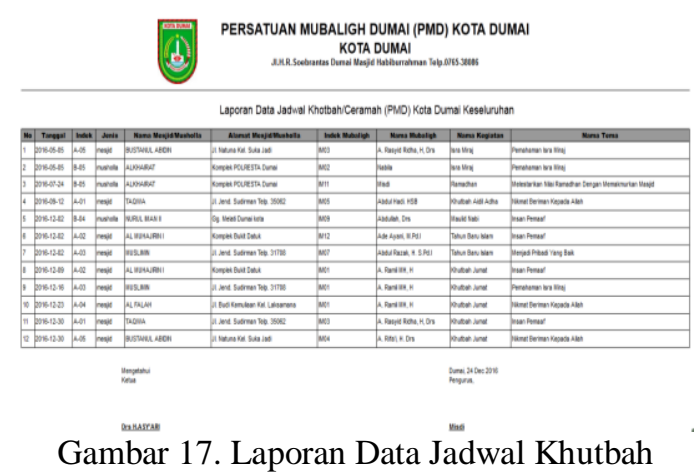

q. Laporan Data Jadwal Per Mubaligh

Pada Menu Utama, pilih Laporan Data Jadwal Per Mubaligh maka akan tampil form Data Jadwal Per Mubaligh, lalu pilih Nama Mubaligh yang ingin dicari seperti gambar 18 dibawah ini :

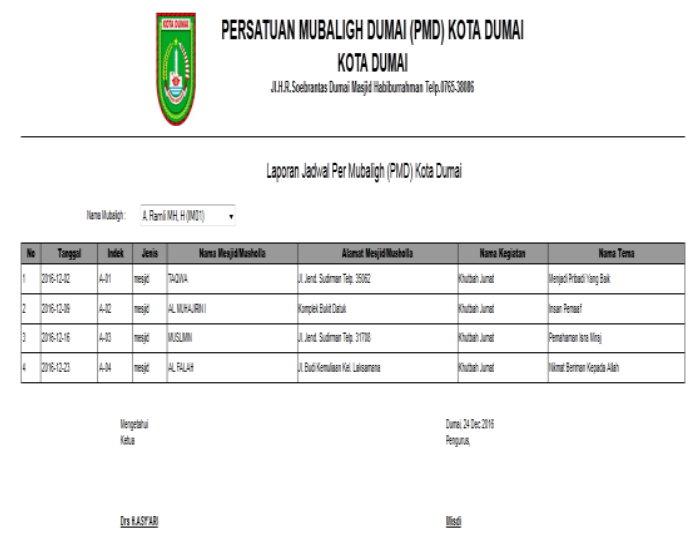

Gambar 18. Laporan Data Jadwal Per Mubaligh

\section{r. Laporan Data Jadwal Per Mesjid}

Pada Menu Utama, pilih Laporan Data Jadwal Per Mesjid maka akan tampil form Data Jadwal Per Mesjid, lalu pilih Nama Mesjid yang ingin dicari seperti gambar 19 dibawah ini :
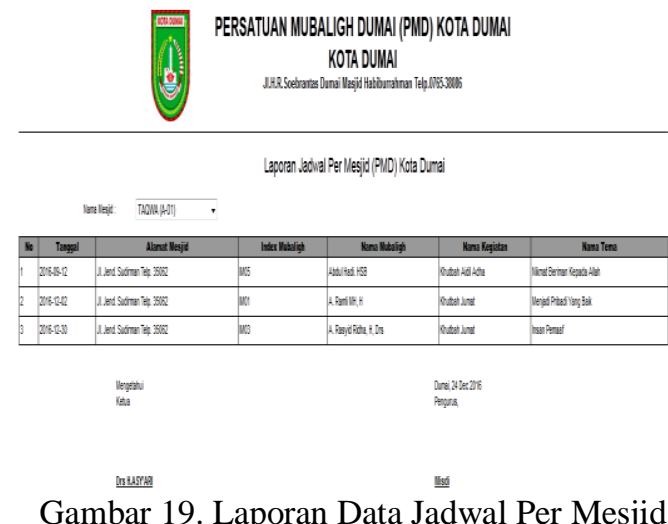
I N F O R M A I I A

Jurnal Informatika, Manajemen dan Komputer, Vol. 9 No. 2, Desember 2017

eISSN : 2580-3042

pISSN : 1979-0694

\section{s. Laporan Data Jadwal Per Musholla}

Pada Menu Utama, pilih Laporan Data

Jadwal Per Musholla maka akan tampil form

Data Jadwal Per Musholla, lalu pilih Nama

Musholla yang ingin dicari seperti gambar 20 dibawah ini :

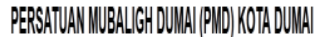

\section{KOTADUMAI}

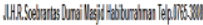

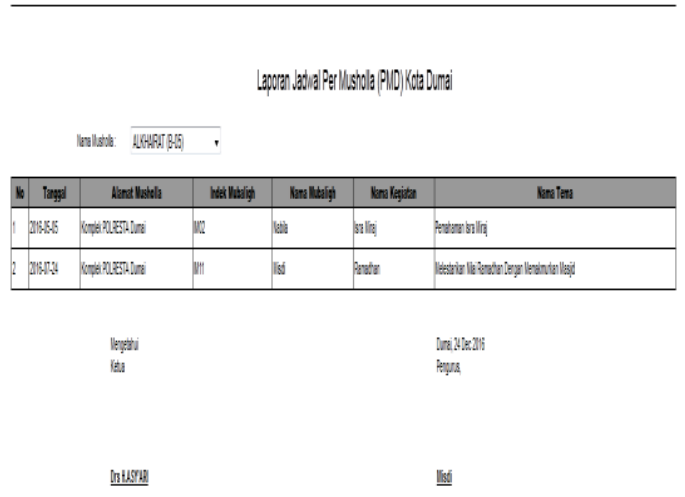

Gambar 20. Laporan Data Jadwal Per Musholla

\section{t. LogOut.}

Klik "LogOut" pada menu utama maka akan menutup aplikasi secara keseluruhan dan memunculkan jendela login.

\section{KESIMPULAN}

Berdasarkan hasil pengembangan sistem Penjadwalan Mubaligh Dumai (PMD) Kota Dumai yang telah dilakukan, maka dapat ditarik suatu kesimpulan dan diajukan beberapa saran yang berhubungan dengan pembahasan yang telah dikemukan dibab bab sebelumnya.

1. Dengan adanya pengembangan sistem aplikasi ini dapat memudahkan para Mubaligh untuk melihat Jadwalnya Masingmasing melalui website yang sudah ada dan para Admin mudah dalam pembuatan laporan, maka dapat dihasilkan laporan dengan cepat dan akurat karena data disusun dalam database dan disimpan dalam media penyimpanan komputer. hal ini di tunjukan apabila data yang di input maka akan tersimpan di dalam laporan.

2. Dengan menggunakan bahasa pemograman PHP dan database SQLyog versi 10.42 pada aplikasi yang dibuat maka dapat membangun suatu aplikasi yang dinamis dan mudah digunakan bagi kantor Persatuan Mubaligh Dumai (PMD) kota Dumai, serta tidak akan ada resiko redudansi data karena jika ada

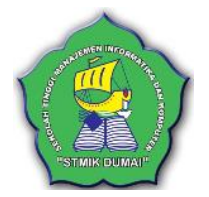

field kunci data yang sama maka data tidak bisa disimpan.

3. Memudahkan admin dalam melakukan pembuatan laporan jadwal khutbah/ceramah Mubaligh Kota Dumai

\section{REFERENSI}

Anggraeni, H. D., Saputra, R., \& Noranita, B. (2013). Implementasi Data Mining dengan Metode Algoritma Apriori dalam Menentukan Pola Pembelian Obat (Studi Kasus di Apotek Setya Sehat Semarang). Jurnal Masyarakat Informatika, ISSN: 2086-4930, Vol. 4, No. 7, Hal: 1-8.

Hanif Al Fatta. (2007). Analisa dan Perancangan Sistem Informasi. Yogyakarta: Andi Offset.

Ignas. (2014). Sistem Informasi Penjualan Online. Jakarta: PT. Elex Media Komputindo.

Jogiyanto HM. (2009a). Analisis dan Desain Sistem Informasi. Yogyakarta: Andi Offset.

Jogiyanto HM. (2009b). Sistem Teknologi Informasi. Yogyakarta: Andi Offset.

Kurnia, B. E. (2014). Perilaku Penemuan Informasi (Information Seeking Behaviour) Mubaligh Muhammadiyah. Journal Universitas Airlangga, 3(3), 1-15.

Mangngenre, S., Rapi, A., Flannery, W., Studi, P., Industri, T., Teknik, F., \& Hasanuddin, U. (n.d.). Penjadwalan Produksi Dengan Metode Branch and Bound Pada Pt . Xyz, 2-6.

Nugroho, A. (2011). Perancangan dan Implementasi Sistem Basis Data. Yogyakarta: Andi Offset. 